\title{
Optimal Sizing of a PV System in Golpayegan, Iran Using Thermal Modeling-based Load Demand
}

\author{
A. Zare and M. T. Iqbal
}

\begin{abstract}
This paper introduces the design and analysis of a Photovoltaic (PV) system to supply the residential load of a house in Golpayegan, Iran. The paper's procedure is the house's thermal modeling employing BEopt software to estimate the load data and then collect the primary meteorological data such as solar irradiance and temperature for the selected site. After these preliminary steps, system optimization for $\mathrm{PV} /$ grid and $\mathrm{PV} /$ diesel/battery models are developed using the HOMER software. The optimization found that the PV array required capacities are $5.17 \mathrm{~kW}$ and 6.19 $\mathrm{kW}$, producing $9,346 \mathrm{kWh} / \mathrm{yr}$ and $11,196 \mathrm{kWh} / \mathrm{yr}$ for standalone and grid-connected PV systems, respectively. The results indicate that solar energy utilization is an attractive option for grid-connected and standalone PV systems, of which the net present costs (NPC) of each system are 12,180 US\$, 40,618 US $\$$, respectively. The system analyses show that adopting either a PV/grid or PV/diesel/battery system causes a reduction in not only dependency on fossil fuel but also in $\mathrm{CO} 2$ emission.
\end{abstract}

Index Terms - Solar energy; PV system; HOMER; BEopt; renewable energy.

\section{INTRODUCTION}

Due to growing attention to climate change, many countries have agreed to reduce carbon emissions based on the Kyoto Protocol. According to the protocol, carbon emissions must be reduced $50 \%$ by 2050 . Hence, those countries attempt to use environmentally friendly sources. To reduce climate change problems, using renewable energy sources is a feasible and effective solution [1]. The commitment of renewable energy systems (RES) promotes clean electricity [2]. In general, RESs are adopted to supply domestic, manufacturing, and farming loads. When considering new technologies in RESs and the nonstationary characteristics of these RE sources, the optimal supervision and reliable power generation performance from RESs has been more critical in investigations done recently. These investigations examine the benefits and drawbacks of RE sources, the optimization of RESs, environmental pollution mitigation, and enhancement in the system's final cost [3][5].

Due to the high availability of solar energy in most countries, its different applications are widely used throughout the world [6]. As manufacturing the solar photovoltaic (PV) devices at a lower cost becomes a reality, PV systems have been extensively adopted in small-sized

Published on December 30, 2020

A. Zare, Memorial University of Newfoundland, Canada.

(corresponding e-mail: azare ${ }^{\circledR}$ mun.ca)

M. T. Iqbal, Memorial University of Newfoundland, Canada.

(e-mail: tariq@mun.ca) applications. They are one of the most promising candidates for investigations and large-scale developments [7].

With an average annual radiation exposure of $4.5 \mathrm{kWh} / \mathrm{m}^{2} /$ day, Iran has a unique potential for using PV systems [8]. Haratian et al. [9] proposed a RES including $\mathrm{PV} /$ wind/batteries for a standalone power generation in Iran; they employed HOMER software to detect the best RES configuration considering an estimated power consumption. Among different RESs configuration, one which was economically the best was the combination of photovoltaic panel and batteries, with a total NPC of 8173 US. Elsewhere Jahangir et al. in [10] presented a hybrid organic Rankine cycle for a domestic location in Rayen, Iran. HOMER software was used to model RES. The results showed that the optimal power system was a hybrid system consists of PV/ wind/diesel/battery with NPC of 268,592 \$. Shirinabadi et al. [11] proposed a grid-connected solar system in Tabriz, Iran, as an agricultural application of solar systems. Simulations showed that $20.164 \%$ of the required energy of selected site was provided by the solar system and $79.836 \%$ supplied by the utility grid. The proposed system decreased the carbon emission by about $508713.5232 \mathrm{~kg}$ annually. Shahinzadeh et al. [12] Proposed RES included wind/PV/microturbine/battery/fuel cell and utilized HOMER software to estimate the size of power generation units in a grid-connected RES located in Nain, Iran.

Optimal planning principally aims to achieve the best RES combination based on the lowest NPC ( $\$ / \mathrm{kWh}), \mathrm{COE}$ (\%), and carbon emission for both grid-connected and standalone power generation systems [9].

In this paper, RE solutions for both standalone and gridconnected power generation for a household in Golpayegan, Iran, are provided to meet the load demand of the selected place. The chosen house's thermal modeling is carried out using BEopt software to estimate the house's power consumption. The most cost-effective system's design has been carried out adopting HOMER Pro based on the estimated load power consumption and technical and economic parameters of power generation components. The load following (LF) dispatch strategy is used to control the systems.

\section{Methodology}

To successfully evaluate any renewable energy system, employing appropriate criteria in the chosen site, it is necessary to make sure that the operational performance of various designs is precisely examined. The following examination frameworks have been selected in this paper:

- Specifications of selected location and load demand data. 
- Metrological data.

- System components.

- Mathematical description.

- Operational control of the system.

\section{A. Specifications of Selected Location and Load Demand} Data

When designing a RES for a house, it is essential to determine the house energy demands accurately. The thermal modeling of a home is used to achieve this goal [13], [14]. As a case study, the selected house is in Golpayegan, Isfahan Province, Iran $\left(33^{\circ} 27^{\prime} 20.5^{\prime \prime} \mathrm{N}\right.$ $\left.50^{\circ} 16^{\prime} 58.3^{\prime \prime E}\right)$. Thermal modeling is completed with residential load estimation using BEopt software to estimate the house's power consumption based on the meteorological data, specification of the house, and the power consumption of typical appliances used by residents.

Since there are substantial natural oil and gas sources in Iran, people do not use electricity for cooking and heating purposes. Thus, the typical load demand is not significant. According to the BEopt results, the house requires an annual energy consumption of $11222 \mathrm{kWh} /$ year (about $30.74 \mathrm{kWh} /$ day average load), as shown in Fig. 1. The monthly and daily load profile and their average for a year were generated and displayed in Fig. 2, which confirms that the load demand is quietly greater in May, June, July, August, and September due to hot temperature use of air conditioner.

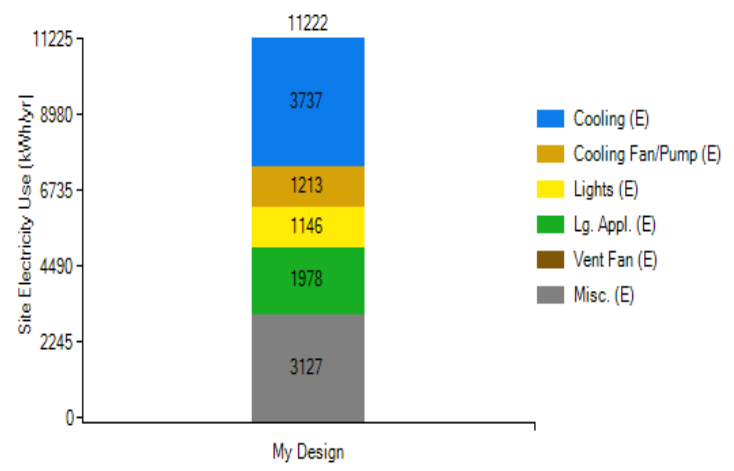

Fig. 1. Annual energy consumption of the house based on BEopt modeling.
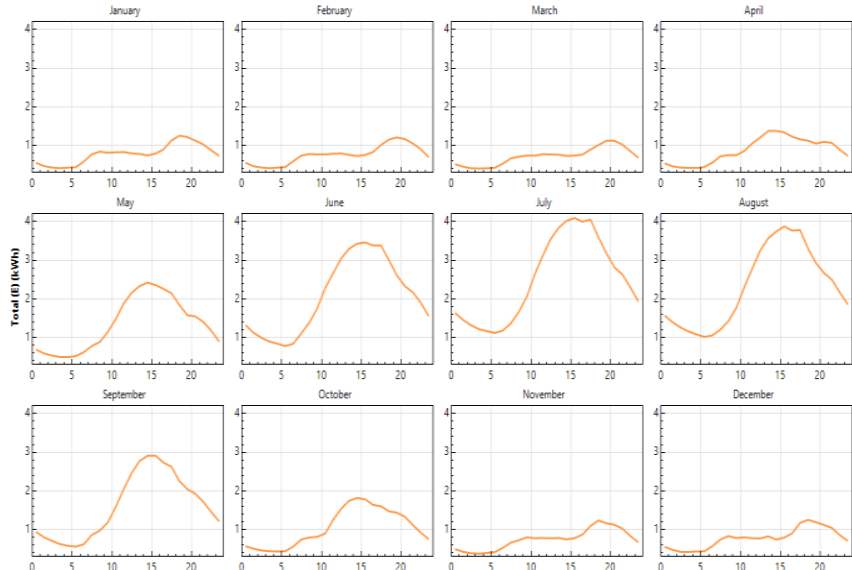

(a)

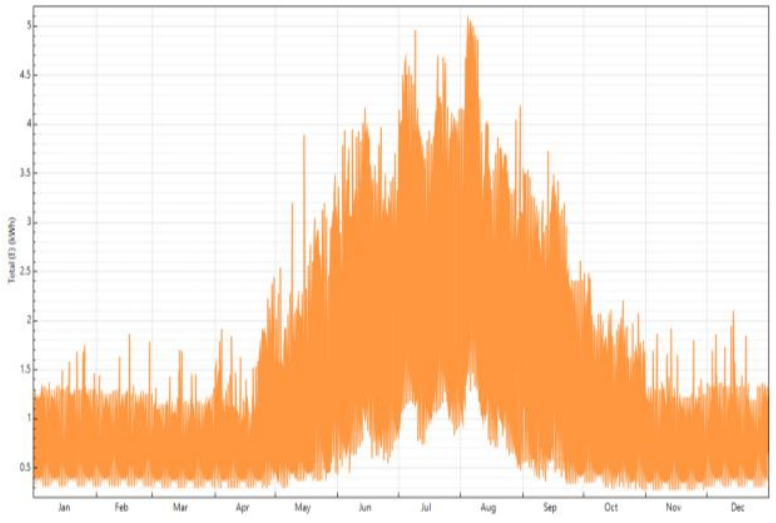

(b)

Fig. 2. (a) Monthly and (b) Daily load of the residence during a year.

\section{B. The Metrological Data}

Solar radiation and ambient temperature significantly impact the PV output power. The following points describe solar irradiance and temperature at the selected city, obtained from the NASA website.

\section{1) Solar radiation}

Fig. 3 presents the solar irradiance and clearance index data for the decided residence. The annual average and the maximum value of solar irradiance are $5.15 \mathrm{kWh} / \mathrm{m} 2 /$ day and $7.61 \mathrm{kWh} / \mathrm{m} 2 /$ day, respectively. Golpayegan city receives a noticeable volume of solar irradiance which confirms that solar power plant is a significant energy source.

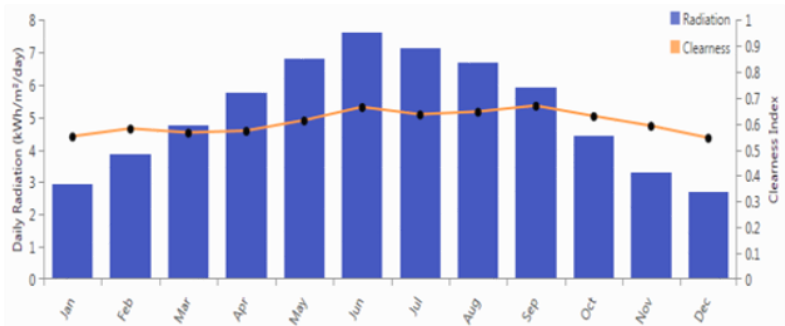

Fig. 3. Monthly solar and clearance index of the selected site.

\section{2) Ambient temperature}

Ambient temperature plays an essential role in the PV panels' performance. Hence, a correct evaluation of ambient temperature data is crucially important. As Fig. 6 demonstrates, the selected site's ambient temperature, summer has the most significant ambient temperature in July at $24.31{ }^{\circ} \mathrm{C}$, and the lowest ambient temperature is in January at $-1.76^{\circ} \mathrm{C}$.

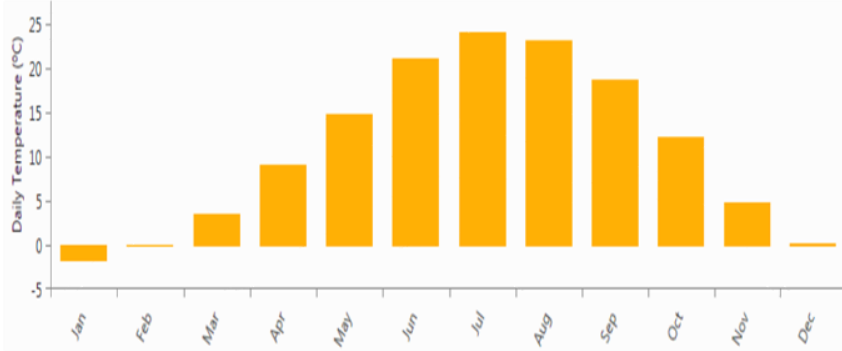

Fig. 4. Monthly temperature of the selected site. 


\section{Power System Components}

In this investigation, two RESs are proposed and investigated. They are then economically compared to each other to find out the best one for the selected site. The first one is a grid-connected RES, consisting of three components: the PV panels, converter, and grid. The second one is a stand-alone RES that comprises four parts: the PV panels, diesel generator, inverter, and some batteries. Schematic diagrams of the purposed RESs are depicted in Fig. 5. The techno-economic information of components for both configurations are defined in specification in Table 1. Imported load data into HOMER software is shown in Fig. 6.

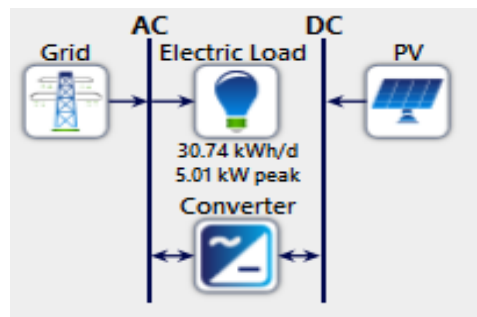

(a)

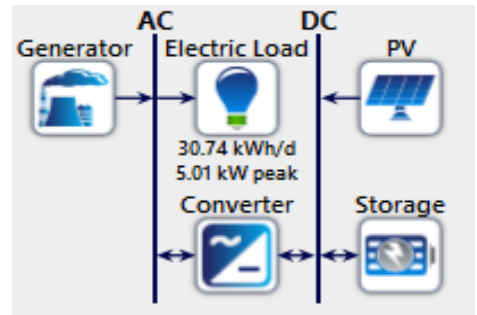

(b)

Fig. 5. Grid-connected PV system (b) Standalone PV system.

TABLE 1: RES COMPONENTS AND THEIR COSTS AND SPECIFICATION

\begin{tabular}{|c|c|c|c|c|}
\hline \multirow[b]{2}{*}{ Component } & \multicolumn{3}{|c|}{ Cost } & \multirow[t]{2}{*}{ Other information } \\
\hline & $\begin{array}{l}\text { Capital } \\
(\$ / \mathrm{kW})\end{array}$ & $\begin{array}{l}\text { O\&M } \\
(\$ / k W)\end{array}$ & $\begin{array}{l}\text { Replacement } \\
\qquad \$ / \mathrm{kW})\end{array}$ & \\
\hline PV panel & 1500 & $\begin{array}{c}10 \\
\text { (1/year) }\end{array}$ & 1125 & $\begin{array}{c}\text { Tracking system: } \\
\text { fixed } \\
\text { Temperature } \\
\text { coefficient }=- \\
0.39 \% /{ }^{\circ} \mathrm{C} \\
\text { Efficiency = } \\
17.72 \% \\
\text { derating factor = } \\
90 \% \\
\text { Nominal } \\
\text { operating cell } \\
\text { temperature = } \\
45^{\circ} \mathrm{C}\end{array}$ \\
\hline Converter & 350 & $\begin{array}{c}10 \\
\text { (1/year) }\end{array}$ & 300 & $\begin{array}{l}\text { Lifetime: } 25 \text { years } \\
\text { Efficiency }=97 \% \\
\text { Lifetime: } 10 \text { years }\end{array}$ \\
\hline Generator & 220 & $0.03(1 / \mathrm{h})$ & 200 & $\begin{array}{l}\text { Lifetime: } 15000 \mathrm{~h} \\
\text { Nominal capacity: }\end{array}$ \\
\hline Battery & 130 & 1 (1/year) & 100 & $\begin{array}{c}200 \mathrm{Ah} \\
\text { Nominal voltage: } \\
1.2 \mathrm{~V}\end{array}$ \\
\hline
\end{tabular}

\section{Mathematical Description}

\section{1) PV generated Power}

The available solar irradiance and temperature considerably influence the output power of PV. The following equation is adopted in HOMER to calculate the PV generated power based on the input parameters [15]:

$$
\begin{gathered}
P_{P V}=Y_{P V, S T C} * f_{P V}\left(\frac{G_{T}}{G_{T, S T C}}\right) * \ldots \\
{\left[1+\alpha_{P}\left(T_{c}-T_{c, S T C}\right)\right]}
\end{gathered}
$$

STC depicts the standard test conditions. $Y_{P V}$ and $f_{P V}$ refer to the PV rated capacity under STCs and derating factor. $G_{T}$ and $G_{T, S T C}$ express incident irradiance on the PV panel at the moment and under STCs, respectively. The coefficient of temperature is represented by $\alpha_{P} . T_{C}$ and $T_{C, S T C}$ are the PV cell temperature $\left({ }^{\circ} \mathrm{C}\right)$ at the moment and under STCs $\left(25^{\circ} \mathrm{C}\right)$, respectively.

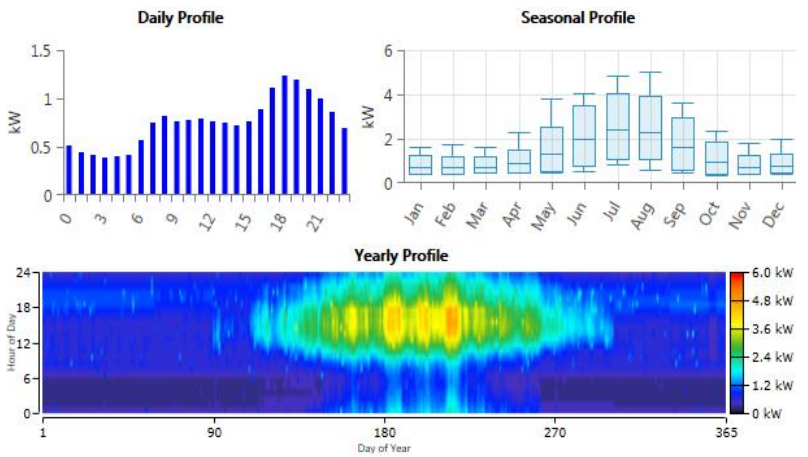

Fig. 6. load profile data into HOMER.

\section{2) Economic design}

Supposing that HOMER software intends to lessen system operating costs and discover the optimal system configuration, economics plays an essential role in related simulations. The optimal combination of RES components is achieved based on the lowest NPC. NPC is a combination of revenues and all expenses over the project lifetime. considering the following equation, the system NPC is obtained as follows [16]:

$$
N P C=\left(C_{\text {ann,tot }} / C R F\left(i, T_{p}\right)\right.
$$

$C_{\text {ann,tot }}$ represents the total annualized cost (\$/year). $i$ refers to the annual interest rate $(\%), T_{p}$ is the endurance of the designed system (year), and $C R F$ indicates the capital recovery factor, which is obtained by [16]:

$$
\operatorname{CRF}(i, n)=\left(\left[i *(1+i)^{n}\right] /\left[(1+i)^{n}-1\right]\right)
$$

In equation (3) $n$ is the number of years. The components' residual values are considered toward the NPC calculation. It is known as salvage costs (SC), which can be obtained using the following equation:

$$
S C=C_{R C}\left(T_{\text {rem }} / T_{\text {com }}\right)
$$

$C_{R C}$ implies the cost of replacement $(\$) . T_{\text {rem }}$ is considered as the remained lifetime of components, and $T_{\text {com }}$ indicates the component lifetime.

the cost of energy has been shown by COE which is obtained by following expression [14]:

$$
C O E=C_{a n n, t o t} / E_{\text {ann,tot }}
$$


$E_{\text {ann,tot }}$ represents the total served electrical load (kWh/year).

\section{E. Control Method}

In this paper, the load following (LF) strategy is presented as a RES controller. The system operation of this controller follows three principles [14]:

1. When the PV output power and load demand are equal, the output power of PV array fulfills the power consumption of the load, so there is no excess power.

2. When the PV generated power is greater than the power consumption of the load, therefore:

- In PV/grid configuration, the excess energy is injected into the grid.

- In PV/diesel/battery configuration, if the battery is fully charged, the excess power is damped. However, the extra power of PV charges the battery if it is not fully charged. In this case, the generator also does not start working.

3. The PV generated power is less than the load required energy; thus:

- In PV/grid, the required energy will be provided by the grid.

- In PV/diesel/battery design, two potential conditions are presents as follows:

- $\quad$ If $\mathrm{SOC}=\mathrm{SOC}_{\min }$, the gross load demand $\left(P_{L}-P_{P V}\right)$ is provided by the generator with no battery charging. If the minimum generated power of generator is greater than the needed gross power demand of the load, then the net load demand is supplied by the generator, while PV charges the battery.

- If $\mathrm{SOC}>\mathrm{SOC}_{\min }, \mathrm{HOMER}$ calculates the battery discharging cost and compares it to the cost of turning the generator on. If the discharging cost of the storage is less than the cost of turning on the generator, the storage will be discharged to meet the load demand. Otherwise, the generator will be run to fulfill the load required energy.

\section{OPTIMAL SIZING RESUlTS AND DISCUSSION}

The technical feasibility is investigated to examine the available power's capability to meet the load demand for a year. Then, HOMER software examines the economic sustainability and environmental consequences of the suggested systems. The uncertain specifications of the power system are shown in Table 2.

The feasible systems can satisfy the load demands and are presented by their NPC in HOMER software. The best optimal combination of RES for PV/grid and $\mathrm{PV} /$ diesel/battery systems are provided in Tables 3 and 4. The electric production for both RES systems is illustrated in Fig. 7 and 8 based on the months.

TABLE 2: UNCERTAIN SPECIFICATIONS OF THE POWER SYSTEM

\begin{tabular}{cc}
\hline \hline Uncertain specification & Value \\
\hline Annual discount rate & $8 \%$ \\
Project lifetime & 25 \\
Maximum capacity shortage & $1 \%$ \\
SOC $_{\text {min }}$ & $25 \%$ \\
Grid power price \& sell back price & $0.1 \$ / \mathrm{kWh} \& 0.08 \$ / \mathrm{kWh}$ \\
Fuel price & $1 \$$ \\
\hline \hline
\end{tabular}

TABLE 3: OPTIMIZATION RESULTS OF THE PV/GRID RES

\begin{tabular}{cc}
\hline \hline Item & Value \\
\hline PV & $6.19 \mathrm{~kW}$ \\
Converter & $5.03 \mathrm{~kW}$ \\
NPC & $12,180 \$$ \\
COE & $0.056 \$ / \mathrm{kWh}$ \\
Renewable fraction & $64.1 \%$ \\
PV production & $11,196 \mathrm{kWh} /$ year \\
Grid purchases & $5976 \mathrm{kWh} /$ year \\
Total production & $17,172 \mathrm{kWh} /$ year \\
Excess energy & $0.5 \%$ \\
Carbon emission & $3,777 \mathrm{~kg} /$ year \\
Capital cost & $5,349.48 \$$ \\
O\&M cost & $5,679.5 \$$ \\
Replacement cost & $1,332.5 \$$ \\
\hline \hline
\end{tabular}

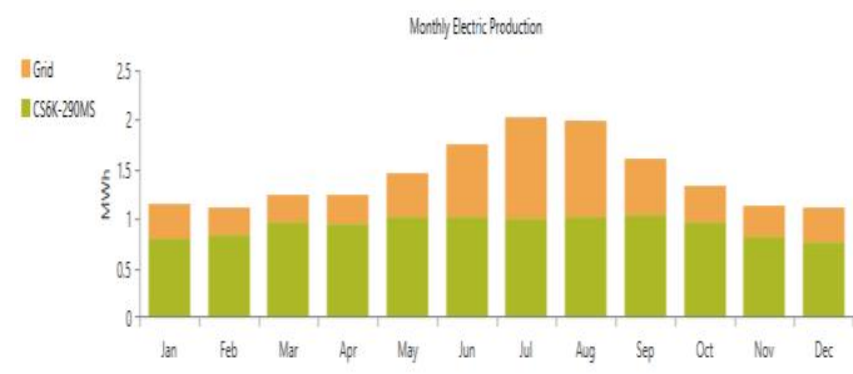

Fig. 7. Generated power of Grid-connected PV system.

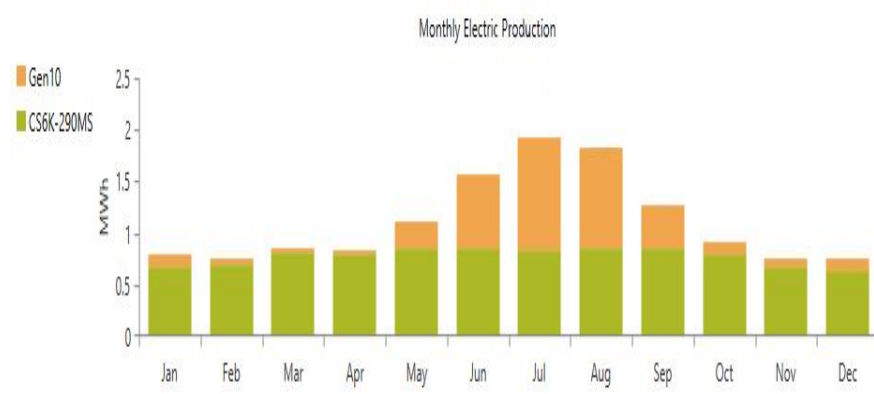

Fig. 8. Generated power of standalone PV system.

TABLE 4: OPTIMIZATION RESULTS OF THE PV/DIESEL/ BATTERY RES

\begin{tabular}{cc}
\hline \hline Item & Value \\
\hline PV & $5.17 \mathrm{~kW}$ \\
Biesel generator & $36 \mathrm{Strings}$ \\
Converter & $10 \mathrm{~kW}$ \\
NPC & $6.67 \mathrm{~kW}$ \\
COE & $40.618 \$$ \\
Renewable fraction & $0.28 \$ / \mathrm{kWh}$ \\
PV production & $64.2 \%$ \\
Grid purchases & $9,346 \mathrm{kWh} /$ year \\
Total production & $4,019 \mathrm{kWh} /$ year \\
Excess energy & $13,365 \mathrm{kWh} /$ year \\
Carbon emission & $8 \%$ \\
Capital cost & $4,969 \mathrm{~kg} / \mathrm{year}$ \\
O\&M cost & $12,210 \$$ \\
Replacement cost & $2,811 \$$ \\
Salvage cost & $1,827 \$$ \\
Battery autonomy & $-819 \$$ \\
Fuel consumption & $12.1 \mathrm{hr}$ \\
\hline \hline
\end{tabular}

Battery autonomy (BT) represents the fraction of time when the storage supplies the load but does not get charged in the primary breakdown. Reaching some BT is essential, mainly when the PV generated power cannot satisfy the load requirement [17]. The $\mathrm{BT}$ is $12.1 \mathrm{~h}$ for $\mathrm{PV} / \mathrm{grid} / \mathrm{batteries}$ configuration based on the simulation results in this investigation. 


\section{CONCLUSIONS}

In this work, the evaluation of RES is technically and economically performed to provide the selected household with power in Golpayegan, Iran. First, the thermal modeling of the chosen house is carried out by using BEopt software. The RES configurations are suggested, which include $\mathrm{PV} /$ grid and PV/diesel/battery. HOMER software adopted to simulate and model these configurations. LF control strategy is adopted in this study to manage the power generation. The cost investigation shows that the PV/grid has a PV array of $6.19 \mathrm{~kW}$ and an inverter of $5.03 \mathrm{~kW}$, and its NPC is $\$ 12,180$ and a COE of $0.056 \$ / \mathrm{kWh}$. However, the optimal solution of PV/diesel/battery configuration consists of a PV array of $5.17 \mathrm{~kW}$, a diesel generator of $10 \mathrm{~kW}, 36$ storage, and an inverter of $6.67 \mathrm{~kW}$. Its net present cost is $\$ 40,617$, and the cost of energy is $0.28 \$ / \mathrm{kWh}$, which is more expensive than the $\mathrm{PV} /$ grid system.

\section{ACKNOWLEDGMENT}

The authors would like to thank the School of Graduate Studies, Faculty of Engineering and Applied Science, Memorial University and Pooya Pajouhan Nirouye Golpa Company.

\section{REFERENCES}

[1] H. Rezzouk and A. Mellit, "Feasibility study and sensitivity analysis of a standalone photovoltaic-diesel-battery hybrid energy system in the north of Algeria", Renewable and Sustainable Energy Reviews, vol. 43, pp. 1134-1150, 2015.

[2] A. Fathima and K. Palanisamy, "Optimization in microgrids with hybrid energy systems - A review", Renewable and Sustainable Energy Reviews, vol. 45, pp. 431-446, 2015.

[3] L. Meng, E. Sanseverino, A. Luna, T. Dragicevic, J. Vasquez and J. Guerrero, "Microgrid supervisory controllers and energy management systems: A literature review", Renewable and Sustainable Energy Reviews, vol. 60, pp. 1263-1273, 2016.

[4] R. Kamel, "New inverter control for balancing standalone micro-grid phase voltages: A review on MG power quality improvement", Renewable and Sustainable Energy Reviews, vol. 63, pp. $520-532,2016$

[5] Z. Shuai, Y. Sun, J. Shen, W. Tian, C. Tu, Y. Li, and X. Yin, "Microgrid stability: Classification and a review", Renewable and Sustainable Energy Reviews, vol. 58, pp. 167-179, 2016.

[6] M. Esen and T. Yuksel, "Experimental evaluation of using various renewable energy sources for heating a greenhouse", Energy and Buildings, vol. 65, pp. 340-351, 2013.

[7] A. Shiroudi, S. Taklimi, S. Mousavifar and P. Taghipour, "Standalone PV-hydrogen energy system in Taleghan-Iran using HOMER software: optimization and techno-economic analysis", Environment, Development and Sustainability, vol. 15, no. 5, pp. 1389-1402, 2013.

[8] G. Najafi a,n, B.Ghobadian a, R.Mamat b, T.Yusaf c, W.H.Azmi b "Solar energy in Iran: Current state and outlook", Renewable and Sustainable Energy, vol. 49, pp. 931-942, 2015.

[9] M. Haratian, P. Tabibi, M. Sadeghi, B. Vaseghi and A. Poustdouz, "A renewable energy solution for standalone power generation: A case study of KhshU Site-Iran", Renewable Energy, vol. 125, pp. 926-935, 2018.

[10] M. Jahangir, S. Mousavi and M. Vaziri Rad, "A techno-economic comparison of a photovoltaic/thermal organic Rankine cycle with several renewable hybrid systems for a residential area in Rayen, Iran", Energy Conversion and Management, vol. 195, pp. 244-261, 2019.

[11] M. Shirinabadi and A. Azami, "The Feasibility of Photovoltaic and Grid-Hybrid Power Plant for Water Pumping Station in Tabriz-Iran," 2018 International Conference on Photovoltaic Science and Technologies (PVCon), Ankara, pp. 1-4, 2018.

[12] H. Shahinzadeh, M. Moazzami, S. H. Fathi and G. B. Gharehpetian, "Optimal sizing and energy management of a grid-connected microgrid using HOMER software," 2016 Smart Grids Conference (SGC), Kerman, pp. 1-6, 2016.

[13] A. Iqbal and M. Iqbal, "Design and Analysis of a Standalone PV System for a Rural House in Pakistan", International Journal of Photoenergy, vol. 2019, pp. 1-8, 2019.

[14] L. Aghenta and M. Iqbal, "Design and Dynamic Modelling of a Hybrid Power System for a House in Nigeria", International Journal of Photoenergy, vol. 2019, pp. 1-13, 2019.

[15] A. Aziz, M. Tajuddin, M. Adzman, M. Ramli and S. Mekhilef, "Energy Management and Optimization of a PV/Diesel/Battery Hybrid Energy System Using a Combined Dispatch Strategy", Sustainability, vol. 11, no. 3, p. 683, 2019.

[16] Y. Alharthi, M. Siddiki, and G. Chaudhry, "Resource Assessment and Techno-Economic Analysis of a Grid-Connected Solar PV-Wind Hybrid System for Different Locations in Saudi Arabia", Sustainability, vol. 10, no. 10, p. 3690, 2018.

[17] K. Tharani and R. Dahiya, "Choice of battery energy storage for a hybrid renewable energy system", Turkish Journal of Electrical Engineering \& Computer Sciences, vol. 26, no. 2, pp. 666-676, 2018. 